\title{
Ön Yargılar ve Sosyal Hizmet: Sosyal Hizmet Bölümü Öğrencilerinin Kadına Karşı Ön Yargıları
}

\author{
Biases And Social Work: Biases Of Social Work Students Towards Women
}

\author{
Mehmet KIRLIOĞLU
}

ÖZ

Bu çalışmanın amacı ileriki yıllarda sosyal hizmet uzmanı/sosyal çalışmacı olarak görev yapacak olan Selçuk Üniversitesi Sağlık Bilimleri Fakültesi Sosyal Hizmet Bölümü öğrencilerinin kadına karşı ön yargılarını ortaya koymaktır. Çalışmada "Kadın” ile ilgili Türkçe literatür taranarak "Kadın” üst başlı̆̆ altında "Boşanan Kadın”, "Hayat Kadını”, "Çalışan Kadın”, "Evlilik Dışı İlişki”, "Ev Hanımı" ve "Flört” başlıkları ele alınmıştır. Araştırmada araştırma yöntemlerinden nitel araştırma deseni kullanılmıştır. Çalışmaya 20 kız ve 20 erkek olmak üzere toplamda 40 öğrenci katılmıştır. Veriler, araştırmacı tarafindan hazırlanan yarı yapılandırılmış görüşme formu ile toplanmıştır. Verilerin toplanmasında mecazlar yolu ile veri toplama tekniğinden de yararlanılmıştır. Daha sonra elde edilen veriler bilgisayar ortamına aktarllarak içerik ve betimsel analize tabi tutulmuştur. Ana temalar literatür doğrultusunda oluşturulmuştur. Ancak alt temalar verilerden elde edilmiştir.

\author{
ANAHTAR KELIMELER \\ Kadına Karşı Ön Yargılar, Çalışan Kadın, Hayat Kadını, Boşanan Kadın, Evlilik Dışı İlişki
}

\begin{abstract}
The aim of this study is to explore the biases of students of Social Work Department in Faculty of Health Sciences, Selcuk University, who will work as a social worker, towards women. Turkish literature reviewed for concepts of "Women" and topics of "Divorced Women", "Prostitute", "Working Women", "Flirting", "Housewife" and "Fornication” were discussed under the title of "Women". The study conducted by qualitative research method. A total of 40 students, 20 girls and 20 boys, participated in the study. The data collected by semi structured interview form and metaphorical technique was also used. The data gathered were transferred into the computer. Data were analyzed by content and descriptive analysis. The main themes were created in accordance with the literature. However, sub-themes were obtained from the data.
\end{abstract}

\section{KEYWORDS}

Biases Towards Women, Working Women, Prostitute, Divorced Women, Fornication.

\begin{tabular}{|c|c|c|}
\hline \multicolumn{2}{|c|}{ Makale Geliş Tarihi / Submission Date } & \multicolumn{1}{c|}{$\begin{array}{c}\text { Makale Kabul Tarihi / Date of Acceptance } \\
\text { 09.02.2019 }\end{array}$} \\
\hline \multirow{3}{*}{ Atıf } & $\begin{array}{l}\text { Kırlığlu, M. (2019). Ön Yargılar ve Sosyal Hizmet: Sosyal Hizmet Bölümü Öğrencilerinin Kadına Karşı Ön } \\
\text { Yargıları. Selçuk Üniversitesi Sosyal Bilimler Meslek Yüksekokulu Dergisi, 22 (1), 25-41 }\end{array}$ \\
\hline
\end{tabular}

\footnotetext{
* Dr. Öğr. Üyesi, Necmettin Erbakan Üniversitesi, Sağlık Bilimleri Fakültesi, Sosyal Hizmet Bölümü, kirlioglumehmet@gmail.com, ORCID ID: https://orcid.org/0000-0003-0130-0841
} 


\section{GİRIŞ}

Toplumsal cinsiyet eşitsizlikleri, ön yargılar ve damgalanma günümüzde sosyal bilimlerin araştırma odağı olan konuları arasındadır. Sosyal hizmetin temel ilkelerinden olan insan hakları, sosyal adalet ve self determinasyon kavramlarını pratiğe dökebilmek, toplumsal yapıdaki mevcut eşitsizlikleri kalıcı hale getiren ön yargıların araştırılmasını gerekli kılmaktadır. Ayrıca bireylerle çalışan sosyal hizmet uzmanının kendi ön yargılarının farkında olması, toplumla uygulamada ise mevzuat-yasa üretimi noktasında mevcut ön yargılarını sosyal hizmetin ilkeleri doğrultusunda dönüşüme uğratmaya çalışması önemlidir. Bu anlamda geleceğin sosyal hizmet uzmanlarının temel cinsiyet eşitsizlikleri ve ön yargılar konusundaki görüşleri bu çalışmada ilgi odağı konumundadır. Çalışmada "Kadın" ile ilgili Türkçe literatür taranarak "Kadın" üst başlığı altında "Boşanan Kadın", "Hayat Kadını", "Çalışan Kadın", "Evlilik Dışı İlişki”, "Ev Hanımı" ve "Flört" başlıkları ele alınmıştır.

\section{Ön yargı}

Ön yarg1; evrimsel, ontogenetik, tarihsel, ekonomik, sosyopolitik alanlardan etkilenen çok boyutlu bir kavramdır. Toplumsal düzeyde ön yargılar, yabancılara karşı hissedilen belli-belirsiz huzursuzluk duygusundan; etnik aşağılama, vahşet ve soykırıma kadar uzanan geniş bir yelpazede karşımıza çıkabilmektedir (İlhan ve Çevik, 2013: 52). Ön yargı, insan kişiliğinin ve dolayısıyla yaşamının ayrılmaz bir parçasıdır. Ön yargılar zamanla insanın gündelik yaşamının bir parçası haline gelir. Çok masum bir şekilde kullanılan cümleler zihinlerde yerleşen ön yargılı düşüncenin uzantısı olabilir. Örneğin çoğu atasözü ön yargılı düşünceyi yansıtır (Kalayc1-Kırlığglu ve diğ., 2016: 117-118). Bunlar küçük yaşta ailede sonra okulda ve hayat boyu çeşitli kitle iletişim araçlarında pekiştirilir, zihinlere yerleşir ve doğal bir hale gelir (Gürel, 2011: 106).

Ön yargılar bireyler tarafindan önceden oluşturulmuş, insanların duygu ve tutumlarına bağlı oluşan yanlılığ göstermektedir. Ön yargılarda peşin hüküm ve klişeleşmiş düşünceler söz konusudur (Uygun, 2006: 2). Ön yargılar oluşurken karşı tarafın düşeceği zorluklar sorgulanmamaktadır. Aslında ön yargılar düşünülmeden oluşturulan kalıp yargılardır yani akıl öncesidir. Bununla birlikte sezgiler ve içgüdüler ile belirlenir. İnsanın varlığına atfedilen her durumu insan psikolojisine ve insan kişiliğine bağlayan psikanalitik yaklaşıma göre ön yarg1, psikodinamik bir süreçtir (Gürses, 2005: 144-146). Ön yargıların ve kalıp düşüncelerin sonucunda ayrımcılık oluşmaktadır. Ayrımcılık, herhangi bir kişinin ön yargılı olduğu bir kişi ya da gruba karşı olumsuz davranmasıdır (Coşkun, 2004: 45). Ayrımcılığın ortaya çımasında en büyük etken ise damgalamadır. Damga, bir kişi ya da grup için utanılması gereken ya da normal olarak kabul edilmeyen davranışların değerlendirilmesidir. Damgalama yapılarak damgalan kişi ya da grup farklılaştırılır ve bu farklılık nedeniyle de damgalı kişilere birçok olumsuz özellik atfedilir. Damgalama sonucu damgalanan kişi ya da gruplar toplumdan soyutlanır (Aker ve ve diğ., 2007: 84).

"Kişilik" ve "ön yargı" birbiriyle ilişkili kavramlardır. Kişilik sayesinde bazı bireylerin diğerlerine neden ön yargilı yaklaşıldığı anlaşılabilmektedir (Gürel, 2011: 119). Geniş grup kimliği, bireysel kimliğin gelişiminin bir parçası olduğundan ön yargıların oluşmasında büyük rol oynamaktadır (İlhan ve Çevik, 2013: 60).

\section{Çalışan kadın}

Günümüzde dünyadaki nüfusun yaklaşık yarısını kadınlar oluşturmaktadır. Ancak kadınların toplumsal ve ekonomik kalkınmadan faydalanma düzeyleri ile ekonomik yaşama katılımlarına bakıldığında aynı oranla karşılaşılmamaktadır (Gökkaya ve Kocacık, 2005: 195-196). Kadının, ücretli olarak çalışma yaşamına katılması, hem kendisi hem de toplum açısından son derece önem teşkil etmektedir. Bu durum da yüzyıllardır süregelen kadının evi ve ailesi ile sınırlı, ekonomik anlamda erkeğe bağımlı rolünü etkilemekte ve onun toplumdaki rollerini değiştirmektedir (Gökkaya ve Kocacık, 2005: 214). Kadın-erkek istihdamına bakıldığında, kadınlar dünyanın her yerinde ve her zaman erkeklerden daha az istihdam edildiği görülmektedir (Çalışma ve Sosyal Güvenlik Bakanlığı, 2010: 4). Türkiye'de kadınlar, toplumsal statüsünde önemli gelişmeler elde etmekle birlikte siyasal yaşama istenilen düzeyde katılamamakta ve annelik rolü içerisine sokularak çalışma yaşamından uzak bırakılmaktadır (Tuncay ve Erbay, 2006: 26). Resmi verilere göre ülkemizde kentsel alanlarda yaşayan kadınların yalnızca \% 15'i işgücüne katılmaktadır (Gökkaya ve Kocacık, 2005: 214). Kadının çalışma hayatında erkeğe kıyasla daha az yer almasında toplumun kadına bakışı, kadına atfettiği roller vs. gibi faktörler etkili olmaktadır. Dolmacı ve Şalvarcı Türeli'ye (2012: 2) göre, toplum kadından içinde bulunduğu konuma veya toplumun kendisine biçtiği role uygun hareket etmesini beklemektedir. Kadına biçilen rollerin içine bakıldığında ise kadının iş hayatında yer alması pek bulunmamaktadır. Aslında bu durum kadın işgücünün yeterince değerlendirilememesi ya da ucuz işgücü şeklinde değerlendirilmesi gibi sonuçlar ortaya çıkarmaktadır. Yani kadın iş hayatında yer alacak ise, daha çok kadın işi olarak ifade edilip, onun evi ve çocukları ile ilgili sorumluluklarını da aksatmayacak bir işte çalışması toplum tarafından uygun 
görülmektedir. Kadının çalışma hayatında daha az yer almasındaki önemli bir faktör de ataerkil aile yapısının çalışan kadına bakışıdır. Ataerkil aile yapısı, kadının çalışmasını bir emek, değer ve fayda olarak görmez. Aile işçisi olarak çalışması kadının zaten yapması gereken bir görevidir. Bu nedenle kadının çalışması değersiz olarak görülür (Tuncay ve Erbay, 2006: 31). Türk toplumunda da ataerkil yapının kadına karşı bakışı aynıdır. Tuncay ve Erbay'a (2006: 353) göre Türk toplumunun sahip olduğu ataerkil aile yapısı, ilerlemeyi ve gelişmeyi engelleyen bazı geleneksel düşünce kalıplarını barındırmaktadır. Bu düşünce kalıplarının kırılamaması da kadınların toplum içindeki statülerinin erkeklere nazaran düşük olmasına neden olmaktadır. İş yaşamı erkeğin geleneksel toplumsal cinsiyet rolü göz önüne alarak şekillendirilmiş olduğundan dolayı iş yaşamında ve toplumsal yaşamda kadının yerini alması daha zorlu bir süreci gerektirmektedir (Dolmacı ve Şalvarcı Türeli, 2012: 2). Sıklıkla karşılaşılan haberlerde kadınların bazı mesleklerde veya iş yerlerinde çalıştırılmalarının arzu edilmemesi ya da işten çıkarılmalarda ilk çıkarılanların kadınlar olması yer almaktadır (Dönmez, 2012: 11; Doğan Haber Ajans1, 2014¹). Yine Tuncay ve Erbaya'a göre (2006: 32) kadınların büyük bir çoğunluğu hala cinsiyet ayrımının belirgin olarak karşılaşıldığı düşük ücretli işlerde çalışmaktadır. Ayrıca kadınlar çalıştıkları konular üzerinde çok fazla kontrol ve güce sahip değillerdir; evde ve işyerinde çok fazla psikolojik taleplerin olması kadınları stres yaratıcı durumlar içerisine sokmaktadır.

\section{Ev hanımı}

Toplum kadını birçok alandan soyutlayarak, özel alan olarak görülen eve ait görmektedir. Kadının zamanının büyük bir kısmını evde geçirmesi, ücretli olarak herhangi bir yerde çalışmaması kadının ev dışına çıkma alışkanlığını yeterince geliştirememiştir. Kadının yaşam alanının ev olarak sınırlandırılması, eve dair sorumlulukların kadına yüklenmesiyle birlikte kadın zamanının çoğunu evde geçirmektedir. Cinsiyetçi bakış kadın-erkek işbölümünü kadının ev içerisinde gerçekleştirmesi gereken işler (ev işi, çocuk bakımı) erkeğin ise ev dışındaki işler olarak görmüştür (Karmaz, 2013: 22-24). Erkeğin ev geçimini sağlamasıyla beraber kadının söz hakkı elinden alınarak kadın pasif bir duruma getirilmektedir (Baykara Acar, 2014: 152). Kadınların çalışma hayatından uzaklaştııılarak eve hapsedilmesinin nedenleri çeşitli kavramlarla açıklanabilmektedir. Kadınların, üst düzey yöneticilik kademelerinde yer almamaları 1980'lerde ortaya çıkan bir kavram olan cam tavan ya da şeffaf tavan (Glass Ceiling) ile açıklanabilir. "Cam tavan kavramı, profesyonel kişilerin (özellikle kadınların) hak ettikleri halde cinsiyet ayrımı nedeniyle üst düzey yönetime ulaşamadıklarını ifade etmektedir. Tavan sözcü̆ü̈, yukarıya çıkmanın engellenmesinden, cam sözcüğ̈̈ ise görülmeyen ama varlı̆̆ı hissedilen bir engelden bahsetmektedir”. Buna göre kadından ailesi ve kariyeri arasında tercih yapması istenilirse kadın ailesini tercih edecektir. Bundan dolayıdır ki, kadınlara iş başvurularında veya işe alınmasında evli misiniz? Ya da çocuk yapacak mısınız? soruları sorulmaktadır (Bilican Gökkaya, 2011: 106-107). Bu durum da kadına yönelik bakış açısını etkileyebilmektedir.

\section{Boşanan kadın}

Ülkemizde en önemli toplumsal kurum olarak kabul edilen aile tüm toplumlarda olduğu gibi erkek ve kadının evlenme kararıyla başlar. Evliliğin toplumca belirlenen kurallar içinde iki ayrı cinsin birlikteliği olduğu göz önüne alınırsa nikâh toplumun onayladığı bir birlik akdi ve ilanı demektir (Aydın ve Baran, 2010: 23-124). Ancak evli çiftler bir çok sebepten dolayı bu birlikteliklerini sonlandırabilmektedirler. Birlikteliğin sonlanması boşanma olarak adlandırılmakta ve Türk Dil Kurumu'na (2014) göre boşanma; karı ve kocanın mahkeme kararıyla birbirinden ayrılması olarak tanımlanmaktadır. Öncelikle boşanma hukuki, sosyal ve bireysel yönü ağır basan, çiftlere yeni mali yükümlülükler, velayet ve ebeveynlikle ilgili yeni sorumluluklar getiren, duygusal ve ruhsal açıdan sıkıntılar doğuran çiftlerin yaşamlarını adeta alt üst eden çok önemli sonuçları beraberinde getirebilmektedir (Sarpkaya, 2013: 30). Bunun yanında boşanan çiftten her biri boşanma süreci boyunca psikolojik olarak zarar görseler de kadın ayrıca utanç, acı ve sıkıntı yaşamaktadır. Bulut (2008: 117-118) bu yargıyı, toplumun boşanmış kadına karşı var olan olumsuz ön yargısından kaynaklandığını belirtmektedir.

\section{Evlilik dışı ilişsi yaşayan kadın}

Kadınların evlilik dışı ilişki kurmaları İslamiyet'in yaygın olduğu toplumlarda kabul edilemez bir durumdur. Türkiye gibi büyük bir kitlenin Müslüman olduğu ve cinselliğin tabu olarak görüldüğü ülkelerde

\footnotetext{
${ }^{1}$ Bingöl'de Ak Parti'den 1'inci sıradan Belediye Meclis üyeliğine seçilen mali müşavir Nurten Ertuğrul, ilk toplantıda Ak Partili Belediye Başkanı Yücel Barakazi'nin, "Başkan vekilliği ve yardımcılığı için kadınlara görev vermeyeceğiz"demesinden sonra meclis üyeliğinden istifa etti.
} 
erkekler cinselliği daha özgür yaşamakta, bundan dolayı yargılanmamakta ama kadınlar için evlilik öncesi cinsel birliktelik kabul görmemektedir. Bundan da anlaşılacağı gibi ülkemizde ahlak konusunda ikiyüzlü bir tutum sergilenmektedir (Berberoğlu ve diğ., 2011: 171-172). Özellikle halk arasında "Erkeğin elinin kiridir, yıkayınca geçer" ya da "Erkek aldatır" şeklindeki ifadeleri ahlak konusundaki ikiyüzlülüğü destekler niteliktedir. Ayrıca bu algı kız ve erkek çocukların yetiştirilmeleri sırasında namusun cinsellikle eş tutulması, kadına ait bir kavram olarak aktarılmasıyla oluşmaktadır (Eroğlu ve diğ., 2007: 35). Hepşen'e (2010: 31-32) göre maalesef erkekler bakir olsa da olmasa da kadından bakirelik beklemektedir. Bekaret, el değmemişlik, kızlık daha önce hiç cinsel ilişkiye girmeme durumudur. Bu kavram her iki cins için de kullanılmasına rağmen günümüzde bu kavram kullanılınca akla sadece kadının bekâreti gelmektedir. Genel olarak her toplumda evlenilecek kadında aranan en önemli özellik bakirelik olmaktadır. Bu da evlilik dışı ilişki yaşayan kadına karşı bakış açısısını olumsuz bir biçimde etkilemektedir.

\section{Flört eden kadın}

Flört aşkın, kaderin ve seçimin kesişmesiyle oluşan bir bütünleşme isteğidir. Aslında aşkla beraber flört, bireyin mutluluğa olan açlığını ve doyumsuzluğunu yansıtır. Çünkü kadınlar ve belki de erkekler sürekli güzellik ve mutluluk isteği, beğenilme isteği taşırlar (Eliuz, 2011: 225). Yılmazçoban'a göre (2008: 151) flört, "evlilik" amaçlı olmaktan çok, "karşı cinsi tanıma" amaçlıdır. Aslında her iki cinsin birbirlerine ilgi, sevgi göstermeleri, beğenilerini ortaya koymaları, övgülerini dile getirmeleri cinsel kimliğin oluşmasına ve kendilerini tanımalarına zemin hazırlıyor olabilir.

\section{Hayat kadını}

Hayat kadını kavramı ortaya atılınca akla ilk gelebilecek bir diğer kavram da "fuhuş" olgusudur. Çünkü fuhuş ve hayat kadını birbirini tamamlayan kavramlar olarak karşımıza çıkmaktadır. Buna ek olarak hayat kadının, fuhuş eylemini gerçekleştiren olması nedeniyle fuhuş kavramından bahsetmek yerinde olacaktır. Hepşen'e göre (2010: 53) fuhuş, bireylerin ait oldukları toplumların normlarına uygun olmayan cinsel ilişkilerde bulunmalarına ve bu ilişkiyi de para gibi karşılıklı menfaatler doğrultusunda yapmalarıdır. Türk Dil Kurumu'na (2014) göre fuhuş kelime anlamı olarak cinsel şenlik olarak ifade edilmekteyken ikinci bir tanım olarak da içinde bulunulan toplumun kurallarına uymayan bir biçimde bir veya birkaç kişiyle para karşılığında cinsel ilişskide bulunmaşeklinde ifade edilmektedir. Dinler açısından ise fuhuş gibi aile ve evlilik kurumunun kutsallığını zedeleyecek her türlü davranışta bulunmak yasaktır (Hepşen, 2010: 53).

Hayat kadınına yönelik ön yargılı bakış açısına sahip olunmasının nedenlerinden biri kadının mal ve erkeğin kölesi olduğunu belirten yaklaşımların varlığından kaynaklanmaktadır (Şengör, 2011). Bu nedenle de erkekler, kadınları egolarını tatmin ettikleri varlıklar olarak görmekte ve onların sahibiymiş gibi davranabilmektedirler (Dalkılıç, 2011). Bu sahiplik de namus kavramı özelinde kadınların çocukluklarından itibaren baskı altında tutulduğu bir unsur olarak karşımıza çıkmaktadır. Ancak yalan söyleyen, hak yiyen binlerce namussuz varken, gerçek namusun bacak arasında aranması akla uygun olmayacak kadar basite indirgenmiş bir durumdur (Alço, 2011).

\section{ARAŞTIRMANIN AMACI}

Toplumsal yaşamın her yönüyle ilgisi olan ön yargı da soyut bir kavram olup, değerleri ve uygulama biçimleri sıklıkla tartışılan bir olgudur. Bu araştırmada sosyal hizmet (1., 2., 3. ve 4. sınıf) öğrencilerinin kadına, boşanan kadına, çalışan kadına, hayat kadınına, kadının evlilik dışı ilişkisine, ev hanımı ve flörte dair ön yargılarının mecazlar yoluyla incelenmesi amaçlanmıştır. Araştırmada öğrencilerin kadına yönelik ön yargılarında geliştirdikleri mecazlar incelenerek, benzerlikler ve farklılıklar anlamında belirli tematik başlıklar altında toplanmıştır (Yıldırım ve Şimşek, 2013: 242) ve öğrencilerin kadın algıları ortaya çıkarılmaya çalışılmıştır.

\section{YÖNTEM}

Bu araştırmada, sosyal olguları çevresi içinde anlamayı ve araştırmayı ön plana alan nitel araştırma yöntemi kullanılmıştır. Nitel araştırma desenlerinden olgubilim deseni bu araştırmanın temel yöntemini oluşturmuştur. Olgubilim deseni; farkında olduğumuz ama derinlemesine ve ayrıntılı bir anlayışa sahip olamadığımız olgulara odaklanmamızı sağlar (Yıldırım ve Şimşek, 2013: 72). Bize tümüyle yabancı olmayan aynı zamanda da anlamını tam olmarak kavrayamadığımız olguları araştırmak için en uygun yöntem olgubilimdir.

\subsection{Katılımcilar}


Araştırma 2016-2017 Akademik Yılı'nda Selçuk Üniversitesi'nde gerçekleştirilmiştir. Araştırmada amaçlı örneklem yöntemlerinden ölçüt örnekleme kullanılmıştır (Büyüköztürk ve diğ., 2017; Patton, 2002; Yıldırım ve Şimşek, 2013). Sosyal hizmet eğitimine devam eden öğrenciler gönüllülük esasına göre araştırmaya dâhil edilmiştir. Kendilerini rahat hissetmeleri durumunda araştırma dâhil olmaları istenmiştir. Ayrıca cinsiyet dengesini gözetmek adına görüşülen her bir sosyal hizmet bölümü erkek öğrencisine karşılık sosyal hizmet bölümü kadın öğrencisi ile görüşülmeye çalışılmıştır. Sosyal hizmet bölümlerinde erkek öğrenci sayısının kadın öğrencilerden çok daha az olmasından dolayı böyle bir yol izlenmiştir. Sonuç olarak katılımcılar 20162017 öğretim yılında 1., 2., 3. ve 4. sınıflarda öğrenim gören sosyal hizmet uzmanı adaylarından oluşmaktadır. Araştırmaya katılan sosyal hizmet bölümü öğrencilerinin yaşları 17-24 arasında değişmektedir. Tablo 1'de katılımc1lara ait bilgiler yer almaktadır.

Tablo 1: Katılımcllara ait sosyo-demografik bilgiler

\begin{tabular}{|c|c|c|c|}
\hline Yaş & $\mathbf{N}$ & Babanın Çalışma Durumu & $\mathbf{N}$ \\
\hline 17 & 1 & Emekli & 9 \\
\hline 18 & 2 & Devlet Memuru & 15 \\
\hline 19 & 6 & Gazeteci & 1 \\
\hline 20 & 11 & Reklamc1 & 1 \\
\hline 21 & 9 & Çiftçi & 4 \\
\hline 22 & 5 & Serbest meslek & 6 \\
\hline 23 & 5 & İşçi & 3 \\
\hline 24 & 1 & & \\
\hline Cinsiyet & $\mathbf{N}$ & Sevgililik İlișkisi & $\mathbf{N}$ \\
\hline Kadın & 20 & Var & 7 \\
\hline Erkek & 20 & Yok & 33 \\
\hline Sinif & $\mathbf{N}$ & Annenin Çalışma Durumu & $\mathbf{N}$ \\
\hline 1 & 10 & Ev hanımı & 35 \\
\hline 2 & 10 & Devlet Memuru & 3 \\
\hline 3 & 10 & İşçi & 2 \\
\hline 4 & 10 & & \\
\hline Önceki Yaşanılan Yer & $\mathbf{N}$ & Anne-Babanın Durumu & $\mathbf{N}$ \\
\hline Köy & 3 & Anne-Baba Sağ ve Birlikte & 39 \\
\hline Kasaba & 4 & Anne-Baba Sağ ve Ayrı & - \\
\hline İlçe & 7 & Anne Vefat Etmiş & - \\
\hline Sehir & 16 & Baba Vefat Etmiş & 1 \\
\hline Büyükșehir & 10 & & \\
\hline Anne Eğitim & $\mathbf{N}$ & Baba Eğitim & $\mathbf{N}$ \\
\hline Okur-yazar değil & 7 & Okur-yazar değil & - \\
\hline Okuryazar & 5 & Okuryazar & 2 \\
\hline İlkokul & 17 & İlkokul & 11 \\
\hline Ortaokul & 3 & Ortaokul & 6 \\
\hline Lise & 4 & Lise & 11 \\
\hline Üniversite & 4 & Üniversite & 10 \\
\hline Aile Tipi & $\mathbf{N}$ & Hayat Kadını İle Tanıșma & $\mathbf{N}$ \\
\hline Geniş Aile & 4 & Evet & 7 \\
\hline Birleșik aile & 2 & Hayır & 33 \\
\hline Çekirdek aile & 34 & & \\
\hline Boşanmaya Şahit Olma & $\mathbf{N}$ & & \\
\hline Evet & 14 & & \\
\hline Hayır & 26 & & \\
\hline
\end{tabular}

\subsection{Süreç}

Katılımcılara araştırmanın amacı ve yöntemi hakkında bilgi verildikten sonra sözlü olarak onamları alınmıştır. İstedikleri zaman araştırmadan ayrılabilecekleri belirtilmiştir. Anonimliği sağlamak adına 
katılımcıları bireysel olarak tanımlayan bilgileri almaktan kaçınılmıştır. Her bir katılımcı ile ilgili olarak dört etiket kullanılmıştır. Bunlar görüşme sırası, cinsiyeti, yaşı ve sınıfı olmak üzere sıralanmaktadır (Örneğin; Görüşme:3, Kadın, 19, 1.Sınıf).

Farkında olduğumuz ama derinlemesine ve ayrıntılı bir anlayışa sahip olamadığımız olgulara odaklanmak (Yıldırım ve Şimşek, 2013: 72) istiyorsak bireylere kendilerini ifade etmelerine izin verilmesi gerektiği ve bu konuda bilgi sahibi olmanın en iyi yolunun derinlemesine görüşmeler aracılığı ile gerçekleşeceği belirtilmektedir (Öktem, 2004). Literatür taraması doğrultusunda hazırlanan yarı-yapılandırılmış görüşme formu aracılığı ile katılımcılarla derinlemesine görüşülmüştür. Yapılandırılmış görüşmelere göre araştırmacıya biraz daha esneklik sağlaması nedeniyle yarı yapılandırılmamış görüşme tercih edilmiştir (Ekiz, 2003). Daha sonra katılımcılara kadın, boşanan kadın, çalışan kadın, hayat kadının, kadının evlilik dışı ilişkisi, ev hanımı ve flörte dair düşünceleri mecazlar aracılığı ile açık uçlu solarak sorulmuştur. Örneğin "kadını; bir nesne, bir şekil, bir varlık, bir hayvan, bir bitki, bir şehir, bir masal ya da film kahramanına benzetmek isteseniz neye benzetirdiniz?" diye sorulmuştur. Bu sorunun ardından nitel araştırmada yaygın bir şekilde kullanılan sondaj sorular (Yıldırım ve Şimşek, 2013) sorulmuştur. Özellikle bu tür soruların arkasına "neden?" sorusu da eklenerek bireylerin ifade ettiği mecaza atfettiği anlam keşfedilmeye çalışılmıştır. Katılımcılar aynı mecazı söyleyebilmelerine rağmen "neden?"sorusu o mecazın işlevini değiştirmektedir.

Görüşmeler öğrencilerin dersinin olmadığı gün ve saatlere göre ayarlanmıştır. Görüşmeler için boş bir sınıf temin edilmiş ve öğrencilerin izni doğrultusunda görüşmeler ses kayıt cihazı ile kayıt altına alınmıştır. Görüşmeler ortalama 35 dakika sürmüştür.

\subsection{Verilerin Analizi}

Verilerin doygunluğa ulaştığı (Guest ve diğ., 2006) düşünüldüğünde görüşmeler sonlandırılmış ve ses kayıt cihazındaki veriler deşifre edilmiştir. Katılımcıların ifadeleri yazıya aktarılarak yaklaşık olarak 40 sayfalık bir veri seti elde edilmiştir. Verilerin analizi için hem içerik hem de betimsel analiz tercih edilmiştir. Verilerin kodlanması işlemi Yıldırım ve Şimşek (2013)'in bahsetmiş olduğu "genel bir çerçeve içinde yapılan kodlama" ile gerçekleştirilmiştir. Diğer bir ifade ile kodlama işlemi hem daha önceden belirlenmiş hem de verilerden çıkarılan kavramlara göre yapılmıştır. Yapılan kodlamalar neticesinde temalar ortaya çıkmış ve verilerin temalara göre düzenlenmesi gerçekleştirilmiştir (Özdemir, 2010). Güvenilirliği sağlamak amacıyla temalar ile ilgili meslektaş denetiminden yararlanılmıştır (Alaee ve diğ., 2015). Doktora tezinde nitel araştırma desenini kullanmış olan iki akademisyenden yardım talep edilmiştir. Akademisyenler önerileri doğrultusunda nihai temalara karar verilerek veri analizi sonlandırılmıştır.

Selçuk Üniversitesi Sağlık Bilimleri Fakültesi Sosyal Hizmet Bölümü öğrencilerinin kadına yönelik ön yargılarını analiz etmek amacıyla yapılan bu çalışmada elde edilen veriler yedi başlık altında ele alınmıştır. Bunlar:

1. Kadın neye benzer?

2. Çalışan kadın hakkında ne düşünüyorsunuz?

3. Ev hanımı hakkında ne düşünüyorsunuz?

4. Boşanan kadın hakkında ne düşünüyorsunuz?

5. Evlilik dışı iliş̧i yaşayan kadın hakkında ne düşünüyorsunuz?

6. Flört eden kadın hakkında ne düşünüyorsunuz?

7. Hayat kadını hakkında ne düşünüyorsunuz?

Araştırmacı tarafından söz konusu başlıklar yedi ana tema ile çerçevelendirilmiş, sonrasında ana temalar alt temalara bölünmüştür. İlgili alt temalar, ifadeler ve katılımcılara ait sosyo-demografik özellikler derlenerek belirli başlıklar altında tablolaştırılmış ve analiz edilmiştir.

\section{BULGULAR ve TARTIŞMA}

Tablo 2: Çalışma kapsamında belirlenen ana temalar, alt temalar ve ifade sayıları

\begin{tabular}{|l|l|l|}
\hline \multicolumn{1}{|c|}{ Ana Tema } & \multicolumn{1}{c|}{ Alt Tema } & N \\
\hline \multirow{3}{*}{ Kadın neye benzer? } & Koruyucu anne & 6 \\
& İlgi bekleyen, narin & 8 \\
& Bereket & 5 \\
\hline \multirow{3}{*}{ Çalışan kadın } & Bağımsı-Özgürlük & 11 \\
& Evini de önemsemeli & 4 \\
& Yorucu-Zor & 6 \\
\hline
\end{tabular}




\begin{tabular}{|l|l|l|}
\hline \multirow{3}{*}{ Ev hanımı } & Zor meslek & 8 \\
& Monoton hayat & 7 \\
& En iyisi & 4 \\
\hline \multirow{3}{*}{ Boşanan kadın } & Toplumda dışlanan & 5 \\
& Gayet doğal & 12 \\
& Güçlü kadın & 4 \\
\hline \multirow{3}{*}{ Evlilik dışı ilişki yaşayan kadınn } & Doğru değil & 10 \\
& Tercih meselesi & 5 \\
& Gayri Ahlaki & 7 \\
\hline \multirow{3}{*}{ Flört eden kadın } & Gayet doğal & 8 \\
& Evliliğe giden yol & 9 \\
& Belirli bir sınırı olmalı & 4 \\
\hline \multirow{2}{*}{ Hayat kadını } & Bataklığa düşmüş & 10 \\
& Toplumun suçu & 10 \\
\hline
\end{tabular}

\section{Kadın Neye Benzer?}

\section{Koruyucu anne}

"Kadını eve benzetirim. Çünkü içerideki sahip olduklarını dışarıdaki zorluklardan, kötülüklerden korur. Aynı zamanda sahip olduklarının bir düzen dâhilinde olmasını sağlar.” (Görüşme:3, Kadın, 19, 1.Sınıf)

"Kadın, canlıların en kutsalıdır. Çünkü hayatı düzenleyen kişidir." (Görüşme:8, Erkek, 20, 1.Sınıf)

"Erkeğin arkasındaki gizli güç. Otoriter." (Görüşme:10, Erkek, 17, 1.Sinıf)

"Kuşa benzetirdim. Annelik duygusu falan." (Görüşme: 13, Erkek, 20, 2.Sınıf)

"Kadın dağ kekliğidir. Çok güzel, çekici ve narindir. Güzel sesiyle bir öttü mü erkek keklikler dayanamaz ve bulmaya çalışırlar. Keklik aynı zamanda yavrusuna zarar verdiğinizi gördüğü anda etrafınızda çırpınmaya başlar ki yavruları saklansın ve zarar görmesinler diye ölmeyi göze alırlar ve genellikle yavruları zarar görmeden kurtulurlar/başarırlar tıpkı gerçek anneler gibi." (Görüşme:28, Erkek, 23, 3.Sınıf)

"Anne. Çünkü dünyada her şeyin ve herkesin üstünde tuttuğum ve sevgi, fedakarlık, anlayış, bilinç konusunda üstün bir yaratılış olduğu kanısındayım." (Görüşme: 36, Erkek, 23, 4.Sınıf)

\section{Illgi bekleyen narin}

“Geyik, elma. Çünkü kibar, yalnız, korunmaya muhtaç, estetik, narin, ilgi bekleyen...” (Görüşme:7, erkek, 20, 1.sinif)

“Kadınları çiçeğe benzetiyorum. Bakıldıkça ilgi gösterildikçe güzelleşir.”(Görüşme:14, kadın, 20, 2.sınıf)

"Kadınları çiçeğe benzetirdim. Çünkü narinliğin ve kutsallığın simgesi olarak görüyorum. Her kadın farklidır.

"Kadın bir çiçeğe benzer. Onun isteklerini ve arzularını karşıladığımız zaman büyür ve güzel bir ortam oluşturur."(Görüşme:19, erkek, 20, 2.sınıf)

"Kuğu. Narin olduğu için.” (Görüşme:20, erkek, 20, 2.sınıf)

“Pembe renkli, pamuk şekeri. Narin, naif yapısı var.” (Görüşme:26, kadın, 21, 3.sınıf)

" Kadın deyince aklıma her an kırılacak, büzülecek çiçek aklıma geliyor. Çünkü kadınlar narin ve hassas oldukları için öyle düşünüyorum." (Görüşme:27, erkek, 23, 3.sınıf)

"Kediye benzetirim. Çünkü bana göre kadınlar erkeklere nazaran daha savunmasız ve güçsüzdürler. Özellikle geleneksel toplumlarda yetişen kadınlar erkeğin otoritesine karşı boyun eğerler." (Görüşme:35, erkek, 21, 4.sinif)

\section{Bereket}

"Ağaca benzetirim. Çünkü kadın aynı ağaç gibi zaman zaman yapraklarını dökse de hayata tutunmayı başarır.”(Görüşme:17, kadın, 19, 2.sınıf)

“Düşündüm ama bulamadım. Kadın kadınlığıyla güzel.”(Görüşme:18, kadın, 19, 2.sınıf)

"Kadın dağıtıcı bir makinaya benzer. Evdeki diğer aile bireylerini koordine eden, onlara sevgi, huzur, güven dağıtan; evi, eşi ve ailesinin anlamlı olmasını sağlayan ailenin en önemli bireyidir." (Görüşme:23, erkek, 21, 3.sinif)

“Kibele’ye benzetirdim. Bereket tanrıçası kadını özetliyor. “(Görüşme:32, kadın, 4.sınıf)

"Kadını bir buğday başağına benzetiyorum. Hayat için oldukça elzemdir.”(Görüşme:33, erkek, 21, 4.sınıf) 
Sosyal Hizmet öğrencilerinin kadına yönelik düşünceleri yukarıda verilmiştir. Öğrencilerin çoğunluğu kadını ilgi bekleyen-narin ve koruyucu anneye benzetmişlerdir. Toplumlarda kadına verilen değer veya değersizlik, bazen bir nesne, bazen bir anne, eş veya tanrıça olarak değerlendirilebilir. Çoğu zaman da kadın tanrısallaştırılmıştır. Ancak buna rağmen değer ve değersizlikle yüz yüze kalmaktan kurtulamamıştır. Toplumlara göre değişiklik gösteren bu değer veya değersizlik dinamiktir (Gülaçt1, 2012: 89). Bu değer ve değersizliğe sebebiyet veren en önemli faktörlerden biri hemen hemen her kültürde kız ve erkek çocuklara doğumlarından itibaren farklı davranılmasıdır. Cinsiyet bir statü olarak algılanmaktadır. $\mathrm{Bu}$ da farklılığa önemli katkı sağlamaktadır. Hem biyolojik etkenler hem de geleneksel değer yargıları, ön yargılı bakış açıları kadın ve erkek cinsleri arasındaki ayrımcı bakış açısını derinleştirmektedir (Dolmacı ve Şalvarcı Türeli, 2012: 2). Örneğin uzun yıllardır kadın için çizilen ideal kadın imajı hemen hemen her kültürde aynıdır. İdeal kadın imajı; pasif, güzel, zayıf ve evcil olarak çizilmiştir. Kadın, çene çalan, dedikodu yapan, dırdır eden ya da kafa şişiren șeklinde tasvir edilmektedir (Alagözlü, 2009: 43-45). Ancak her bireyin kendine has ve bağımsız olduğu gözden kaçırılmamalıdır (Sürgevil, 2008: 112).

\section{Çalışan Kadın}

\section{Bă̆ımsız-özgürlük}

"Her kadının ekonomik özgürlüğü olmalıdır. Her kadın kimseye bağımlı halde yaşamamalıdır." (Görüşme:1, kadın, 19, 1.sınıf)

"Kadınlar ne babalarına ne eşlerine ekonomik olarak bağımlı olmamaları gerekir. (Görüşme: 2, Kadın, 18, 1.Sinıf)

"Çalışan kadın bence ayaklarının üstünde durabilen kadındır. Geçmişten günümüze kadar kadınlar hep bir naif, zayıf olarak görülmüștür. Ve hepsi olmasa da bir kısmı ezilmeye mahkum olmuștur. Ekonomik gücünün olması kadının kendi fikirlerinin düşüncülerini rahatça ifade etmesini sağlayacaktır." (Görüşme:3, kadın, 19, 1.sinif)

"Her kadının ekonomik özgürlüğü için çalışması ve kendi ayakları üstünde durması gerekir. Çalışan kadınları takdir ediyorum." (Görüşme:4, kadın, 18, 1.sınıf)

"Çalışan kadın güçlü, ayakları sağlam basan kadındır." (Görüşme:5, kadın, 20, 1.sınıf)

"Olması gereken bir durum.”(Görüşme:6, erkek, 19, 1.sinıf)

"Ailede çocuklara bakamıyor, ihmal ediyor. Bazen ekonomik özgürlügünü kullanarak aile içi şiddeti sağl1yor. Eşler birbirinden habersiz, beraberce bir vakit geçiremiyor." (Görüşme:7, erkek, 20, 1.sinıf)

"Hayatınız kazanması ve kendi ayakları üzerinde durabilmesi için çalışmalıdır." (Görüşme:8, erkek, 20, 1.sinif)

"Çok gerekli olmadıkça çalışması taraftarı değilim.” (Görüşme:9, erkek, 19, 1.sınıf)

"Maddi özgürlüğü olan.”(Görüşme:10, erkek, 17, 1.sinıf)

“Kendi ayakları üstünde durması için çalışmalı.”(Görüşme:14, kadın, 20, 2.sınıf)

\section{Evini de önemsemeli}

"Saygı duyarım fakat aile bir iş bölümü kurumudur. Erkeğin görevi çalışmaksa kadının ki de ev işleridir." (Görüşme:11, erkek, 20, 2.sinif)

“Aile ekonomisi açısından gündüz vardiyası olmak şartıyla gayet normal bir durumdur."(Görüşme:12, erkek, 20, 2.sinif)

"Annelik görevi aksarsa çalışmamalı." (Görüşme:13, erkek, 20, 2.sınıf)

"Çalışma saat ve koşulları uygun ise (Görüşme:14, kadın, 20, 2.sınıf)

\section{Yorucu-zor}

"Çalışan bir bayanın işinin çok zor olduğunu düşünüyorum. Birçok role girmek zorunda kalıyor ve bu bana göre yorucu. "(Görüşme:16, kadın, 20, 2.sınıf)

"Zor durumda kaldığına inanıyorum. Her ne kadar eşi yardım etse de o sorumluluğun varlığı ağır olmalı.”(Görüşme:18, kadın, 19, 2.sınıf)

"Kadınların çalışması günümüz de bir gerekliliktir diyebiliriz. Ancak her bireyin kendi fitratına, yapısına uygun işleri yapması gerekir. Kadınlar içinde bu kaide göz önünde bulundurulmalıdır." (Görüşme:31, erkek, 22, 4.sınıf)

"Çalışan bir erkekten hiçbir farkı yok benim için fiziki şartları taşıyan her insan kadın-erkek çalışabilir.”(Görüşme:33, erkek, 21, 4.sınıf)

"Evli çalışan bir bayan için şartlar zor olabilir." (Görüşme:34, kadın, 21, 4.sınıf) 
"Benim annem de çalıştığı için zorluklarını biliyorum diyebilirim. Çalışmak her insan için zor. Ama toplumun kadına anlamsız olarak yüklediği yükler altında çalışan kadınlar ezilmektedir. Bilinçli bir erkek ev sorumluluğunu paylaşır. Sorumluluk eşit olursa sorunlar en aza iner.” (Görüşme:40, kadın, 22, 4.sınıf)

Sosyal Hizmet öğrencilerinin çalışan kadın ile ilgili düşünceleri yukarıda verilmiştir. Öğrencilerin çalışan kadın hakkındaki düşünceleri daha çok "bağımsızlık" ve "özgürlük" temaları altında toplanmıştır. Bazı öğrenciler çalışan kadının aynı zamanda evde de sorumlulukları olduğunu hatırlatmaktadır. Çalışan anneler ve çocukları üzerinde yapılan araştırmalar sonucunda çocukların, annelerinin çalışmasından rahatsız olmadıkları, bu kanının toplumda var olduğu ortaya çıkmıştır (Aktaş, 1994: 8). Ancak Beydili ve diğerlerine göre (2013: 46) hemen hemen bütün toplumlarda toplumsal cinsiyete dayalı işbölümü nedeniyle erkek bireyler çalışma hayatına girmişken, kadın bireyler annelik rolüne bağlı olarak ev hayatı ile özdeşleşmiştir. Buna ek olarak iş hayatına dahil olan kadının işte başarılı olduğu, kadının uzmanlaşma ve kariyer yapma isteği arttığı (Türkkahraman ve Şahin, 2010: 82) bilindiğinden kadına geleneksel ev rolleri sürekli olarak hatırlatılmaktadır.

Kadının, ücretli olarak çalışma yaşamına katılması, hem kendisi hem de toplum açısından son derece önem arz etmektedir. Günümüzde çalışma hayatında sayısı gün geçtikçe artan kadın nüfusu, ekonomik anlamda bağımsızlık kazanmakta, ailesinde ve toplumda üstlendiği rollerde de ikilik yaşamaktadır. Kadın, çalışma yaşamına katılmakla ekonomik bağımsızlığına kavuşmakta, ancak bu bağımsızlık ekonomik yönden erkeğe olan bağımlılı̆̆ını ortadan kaldırmamaktadır (Gökkaya ve Kocacık, 2005: 214-215). Başka bir ifade ile kadın çalışsa da evdeki sorumlulukları her daim devam eder ve bu nedenle ikinci sınıf vatandaş statüsünü devam ettirir ve geleneksel rollerden kurtulamaz (Ümit, 2011). Bu nedenle de kadının geleneksel rollerden kurtulamamasının önündeki düşünceler kalkmadığı sürece kadına bakış açısında bir değişiklik beklenmemelidir.

\section{Ev Hanımı}

\section{Zor meslek}

"Ev hanımı geleneksel olarak bakarsak kutsal bir meslek ama emekliliği gelmeyen hep kendinden taviz veren bir meslektir. Ev içerisine gözle görülen bir iş yapmıyormuşçasına görülür. Fakat en zor meslektir." (Görüşme:3, kadın, 19, 1.sinıf)

"Ev hanımlığı belki dünyadaki en zor işlerden biridir. Ev hanımı en az çalışan hanımlar gibi özel ve önemlidir." (Görüşme:5, kadın, 20, 1.sınıf)

"Ev işlerinin yürütülmesini üstlenen, saçını süpürge eden karakterdir. Ailenin yeri önemli ve büyüktür." (Görüşme:12, erkek,20, 2.sınıf)

"Bana biraz ev işlerine tıkanmış bir görüntü çiziyor. (Görüşme:15, kadın, 22, 2.sınıf)

"Bütün gün ev işleri arasında bocalayan bir kadın.”(Görüşme:17, kadın, 19, 2.sınıf )

"Zor bir iş." (Görüşme:20, erkek, 20, 2.sınıf)

"Ev hanımı olarak 'Kadın'ın evin tüm düzeninden sorumlu, evde her şeyi bilmesi gereken, her işin altından kalkarak her şeye yetişmesi gereken kişi algısı; kadını yüklendiği sorumlulukların altında boğmaktadır, her şeye yetişme telaşıyla kadını tüketmektedir.(Görüşme: 38, Kadın, 23, 4. Sınıf)

"En az iş dünyasına giren kadın kadar hatta zaman zaman daha fazla yıprandığını ve çalıştığını düşünüyorum.” (Görüşme:33, erkek,21, 4.sınıf)

\section{Monoton hayat}

"Ev hanımına karşı değilim ancak ev hanımı olan kadınların yaşamlarının ev işi, çocuk bakmak, yemek yapmaktan ibaret olmasına karşıyım. Ev hanımı olan kişinin hayatı bu kadar kıt olmamalı en azından gündemden haberdar olmalı ve bu konuda bilgi sahibi olmaya çalışmalı. Bunun dışında kendini ihmal etmemeli sosyal aktiviteleri olmalıdır." ( Görüşme:21, kadın, 23, 3.sınıf)

"Bu yüzden özgüven eksikliği yaşama olasılığı yüksektir. Kendini geliştirme firsatını çok bulamaz ya da gayret göstermez. Ev onun için çerçeve içinde bir fotoğraf gibidir.” ( Görüşme:22, kadın, 3.sınıf)

"Evine, eşine, çocuklarının peşine koşup, komşularla (sadece sınırlı sosyal çevre) iletişim sağlayan, yorgun kadın." (Görüşme:26, kadın, 21, 3.sınıf)

"Sıkıcı bir hayat olarak görüyorum." (Görüşme:32, kadın, 4.sınıf)

"Her gün rutin işleri yapmak sıkıcı olsa gerek." (Görüşme:34, kadın, 21, 4.sınıf)

Temizlik, yemek, ev ihtiyaçlarının gelir giderleri, çocukların bakımı ve eğitimi gibi ev işi ve çocuk bakımı yüzünden kendini geliştirmeye firsat bulamamalarına neden olmaktadır." (Görüşme:38, kadın, 23, 4.sınıf)

"Ev hanımları genelde ev de hayatlarını geçiriyorlar. Bence bir kadın eğitim düzeyi ne olursa olsun kendini yetiştirmeli ve topluma katılmalıdır. Bunun için kurslar ve kişisel gelişim olanakları mevcuttur. Kadının yeri 
erkeğin yanında toplum hayatına katılmak olmalıdır. Ülkemiz de buna engel bir toplum baskısının olduğunu düşünmekteyim.” (Görüşme:40, kadın, 22, 4.sınıf)

\section{En iyisi}

“İyi bir şey çocuklarına çok yakından destek olduğu için.” (Görüşme:6, erkek, 19, 1.sınıf)

"Ailesiyle ilgilenmekte zorlanan kadının çalışmaması daha mantıklı tabi." ( Görüşme:25, kadın, 21, 3.sınıf)

"En iyisi. Çocuğuna bakar. Bir çocuk için annesinin yerini kimse dolduramaz." (Görüşme:7, erkek, 20, 1.sinif)

"Bir kadının yeri evinin içidir. Bu konuda düşüncelerim tam pozitif yöndedir.” (Görüşme:9, erkek, 19, 1.sinif)

Sosyal Hizmet bölümü öğrencilerinin ev hanımı ile ilgili düşüncelerinin ev hanımlığının zor bir meslek olduğu ve monoton hayata sebebiyet verdiğine yöneliktir. TÜİK tarafindan yapılan araştırmaya göre (2009) aktif işgücüne katılmayan kadınların \% 62,3'ü ev işleriyle uğraştıklarını ifade etmekte, başka bir deyişle yaklaşık 12 milyon kadın ev hanımı olduğunu ifade etmektedir. Bu durum "ev hanımlığı" olgusunun bir çalışan kadın algısı oluşturmadığı biçiminde yorumlanabilir. Bir erkek evlendiği kadından asıl görev olarak, çocuk özellikle de erkek çocuk- yapmasını, ona yumuşak ve itaatkâr davranarak onun cinsel ihtiyaçlarını her an karşılamasını bekler. Bir de kırsal kesimde kadın, aileye katılmış ev ve tarla işlerinde kullanılacak ücretsiz bir işgücüdür. Bundan dolayıdır ki kadının evde çalışması makbul görmektedir (Gülendam, 2007: 176). Kadının doğumundan itibaren bir sahibi vardır ki topluma göre kadının evlenmesiyle beraber yeni sahibi (kocası) olur. Evlendikten sonra da kadının bu sahibine (kocası) itaat etmesi, dişi kuş olarak kurduğu yuvasını sürdürmesi, çocuk yapması ve bakması beklenir (Baykara Acar, 2014: 147). Özelde annelik genelde ev hanımlığı, toplum tarafından kadını pasifize etme amacıyla kullanılır ve bunda başarılı olunur. Çünkü kadın, ötekiliğini gönüllü olarak kabul etmektedir. Kadın, erkeklere hizmet ettiği ve annelik rolüne yoğunlaştığı oranda toplamda kabul görür. $\mathrm{Bu}$, onun kendisini özne olarak görmesini sağlar ama aslında kendi kendini kandırmaktan başka bir şey değildir (Eliuz, 2011: 226).

\section{Boşanan Kadın}

\section{Toplumda dışlanan}

"Toplum tarafından hoş karşılanmadığı için toplumda büyük sıkıntılar yaşamaktadır. (Görüşme: 1, Kadın, 19, 1. Sinif)

"Anadolu toplumunda boşanmak pek hoș karşılanmaz. Buna rağmen aile ve mahalle baskısını göze alıp bu tür zor karar verebilmek güçlü bir duruş ister. (Görüşme: 15, Kadın, 20, 2. Sınıf)

"Dul kaldığı için tekrar bekâr biriyle evlenememe, aileye karşı sürekli hesap verme ve kontrol edilme, davranış ve hareketlerde kısıtlanma, toplumsal baskı, toplumda artan mesafeli ilişkiler gibi toplum yargıları nedenlerle yaşam alanları son derecede daralmaktadır." (Görüşme:38, kadın, 23, 4.sınf)

Bu ülkede boşanmış kadınlara pek iyi gözle bakılmıyor."(Görüşme:16, kadın, 20, 2.sınıf)

"Zor bir süreçten geçmekte olduğu, toplumda yapılan etiketlemeler yüzünden zorlanacağı. Boşanan kadının çalışan bir birey olduğu veya ev hanımı olması şartları belirgin bir şekilde değiştirebilir." (Görüşme:34, kadın, 21, 4.sinif)

\section{Gayet doğal}

"Diğer kadınlardan bir farklarının olduğunu düşünmüyorum.” (Görüşme:6, erkek, 19, 1.sınıf)

"Anlaşamamışsa boşanmıştır. Kendi tercihidir." (Görüşme:8, erkek, 20, 1.sınıf)

"Hiç hoş ve güzel bir şey değil ama gerekli ise kaçınılmamalı." (Görüşme:9, erkek, 19, 1.sınıf)

"O aşamaya gelmişse yapacak bir şey yoktur." (Görüşme:12, erkek, 20, 2.sınıf)

"Ekonomik olarak sıkıntı çekmiyorsa hiçbir problemi yok."(Görüşme:19, erkek, 20, 2.sınıf)

"Düşünülecek pek bir şey yok. Kendi kararıdır saygı duyuyorum. Kimse boş yere ayrılmaz, kendisine göre mantıklı bir sebebi vardır." (Görüşme:28, erkek, 23, 3.sınıf)

"Onu buna iten sebeplerin önemli olduğu kadını yaftalamamak gerektiğini düşünüyorum. Normal kadın nasılsa boşanmış kadın da öyledir.” (Görüşme:32, kadın, 4.sınıf)

"Insanlar evlenebildikleri gibi boşanabilirler de." (Görüşme:25, kadın, 21, 3.sınıf)

"Eşiyle anlaşamamış, çatışma yaşayıp birlikteliğe devam edemeyen kadın." (Görüşme:26, kadın, 21, 3.sinif)

"Yürümeyen bir evlilik varsa ve kurtarmak için tüm çareler denendiyse her iki tarafında gereksiz acı çekmesini önlemek amaciyla boşanma kabul edilebilir. (Görüşme: 33, Erkek, 21, 4. Sınıf) 
"Her insan evlenip boşanabilir gayet olası ama kadın boşandıktan sonra psikolojik destek almalıdır." (Görüşme:4, kadın, 18, 1.sınıf)

"Boşanma sadece erkeğe verilen bir hak değildir. Toplum olarak kadının boşanması her ne kadar hoş karşılanmasa da boşanma kadının en doğal hakkıdır.” ( Görüşme:21, kadın, 23, 3.sınıf)

\section{Güçlü kadın}

"Kendi ayakları üstünde durması ve çocukları varsa daha güçlü olması gerektiğini düşünüyorum." (Görüşme:14, kadın, 20, 2.sınıf)

$\mathrm{Bu}$ yüzden boşanmış kadın deyince aklıma kararlarında güçlü, risk göze alabilen, tek başına hayata tutunmaktan korkmayan kararlı kadınlar gelir.”(Görüşme:15, kadın, 22, 2.sınıf)

"Boşanan kadın hayatın bütün yükünü omuzlarına almış kadındır. Toplumdaki görevi zordur ve tehlikeye açıktır." (Görüşme:5, kadın, 20, 1.sınıf)

"Hayatının geri kalanını ya da bir kısmını kendi ayakları üstünde durarak geçireceği için gittikçe daha güçlü bir yapıya sahip olur.” (Görüşme:35, erkek, 21, 4.sınıf)

Çiftler anlaşarak çeşitli yollarla evlilik statüsüne ulaşırlar. Ancak evlenerek elde edilen statü boşanma ile kaybedilir ve bu yeni durum, kadınlar için birçok ayrımcılık, dışlanma ve eşitsizlik sorunlarını da beraberinde getirmektedir. Bir kadın boşandığında toplumun hafızasında olumsuz çağrışımlar oluşur. Bu olumsuz çağrışımlar nedeniyle boşanmış kadına yönelik bir baskı ve kontrol refleksi geliştirilmektedir. Kadınlar özellikle boşandıktan sonra karşılaştıkları baskıdan dolayı, yaşadıkları yerde ikamet etmeye devam etmek istememektedirler. Farklı yerleşim yerlerinde kendilerine -varsa- ve çocuklarına yeni bir yaşam kurmak için istekli olmaktadırlar (Akgül Sarpkaya, 2013: 31-32)

\section{Evlilik Dıșı İlișki Yașayan Kadın}

\section{Doğru değil}

"Evlilik kutsal bir kurumdur. O kuruma ihanet etmiştir." (Görüşme:8, erkek, 20, 1.sinıf)

"Tam bir rezillik, şiddetle kınıyorum. Allah kimsenin başına vermesin. Çok kötü ahlaksızca bir yaşam.”(Görüşme:9, erkek, 19, 1.sinıf)

"Bence yanlış bir davranış.”(Görüşme:14, kadın, 20, 2.sınıf)

"İlk duyduğumda "insanlık dışı" diyebilirim. Fakat onu buna iten durumları bilmek gerek. Kendi rızası var ise bunu tamamen kişiliksiz olarak nitelendiririm.”(Görüşme:18, kadın, 19, 2.sınıf)

"Bana göre evlilik gibi bir kurum olmadan bireylerin aynı ortamda yaşayarak ilişki yaşamalarını gereksiz ve uygunsuz bir hareket olarak değerlendiriyorum." ( Görüşme:22, kadın, 3.sınıf)

"Bence affedilmeyecek bir durumdur, bu kadın gözümde karaktersiz ve değersiz en aşağılık bir varlıktır." (Görüşme:23, erkek, 21, 3.sınıf)

"Evlilik dışı ilişki er ya da geç mutsuzlukla sonuçlanmaya mecburdur." (Görüşme:5, kadın, 20, 1.sınıf)

"Kötü yola düşmüş ya da zorla bu ilişkiyi yaşamış olabilir veya evli olduğu halde kocasını aldatıyor olabilir. Tabi bu durum affedilmeyecek kadar kötüdür.” (Görüşme:27, erkek,23, 3.sınıf)

"Evlilik dışı yaşamı ahlaksızca buluyorum bu şekilde yaşayan bir kadını ise kesinlikle onaylamıyorum.”(Görüşme:33, erkek, 21, 4.sınıf)

"Yanlış bir düşünce ve anlayış olduğu kanısındayım. Çünkü insanlar bazı özel durumlarını sevdiği evlendiği kişiyle paylaşması gerektiği inancındayım. Eğer bu ilişkiyi yaşayacaksa da karşı tarafın bekar olmasını tercih ederim.” (Görüşme:36, erkek, 23, 4.sınıf)

\section{Tercih meselesi}

"Tercih meselesi." (Görüşme:6, erkek, 19, 1.sınıf)

"Kendi kararı." (Görüşme:10, erkek, 17, 1.sınıf)

"Doğru anladıysam evlenmeden yapılan cinsel ilişkiyi soruyorsunuz. Cinsellik veya hayat tarzının herhangi bir formaliteye bağlı kalmasından yana değilim. Bu tür bir kadını yadırgamama kendi karaları ve yaşam tarzı ancak ve ancak onu ilgilendirir. "(Görüşme:15, kadın, 22, 2.sınıf)

"Herkesin kendine göre bir yaşam tarzı vardır. Her ne kadar evlilik dışı ilişki yaşamak benim yaşam tarzıma uygun olmasa da bu durumda olan ilişkilere de yadırgayarak bakmam. Herkesin özel bir yaşamı vardır ve diğer insanların bu özel yaşam sınırını iyi bilmelidir." (Görüşme:21, kadın, 23, 3.sınıf)

"Her ne kadar normal karşılanmayan bir durum olsa da kimsenin müdahale etmeye hakkı olmadığını düşünüyorum, herkes kendi yaşantısını seçme hakkına sahip olmalıdır." (Görüşme:37, kadın, 24, 4.sınıf) 
"Ahlaki açıdan oldukça olumsuz bir durumdur." (Görüşme:12, erkek, 20, 2.sinıf)

"Sadakatsizlik bana göre çok kötü bir durum. Bunu yapan kadın ise de erkek ise de kötü gözle bakarım. "(Görüşme:16, kadın, 20, 2.sınıf)

“Ahlaki yönden yozlaşmış kadın. ”(Görüşme:17, kadın, 19, 2.sınıf)

"Geleneksel toplum normlarından, değerlerinden, ahlaki ölçütlerinden hiçbir şey alamamış, kazanamamış kişi olarak tanımlayabilirim.”( Görüşme:24, erkek, 22, 3.sınıf)

"Dinim gereği bunu uygun bulamamaktayım." (Görüşme:25, kadın, 21, 3.sınıf)

"Kendi cinsel ihtiyaçları dışında kimseyi düşünmeyen, bizim kültürümüze uymayan bir durumdur." (Görüşme:28, erkek, 23, 3.sınıf)

"Ahlaki bir problemdir. Evlilik dışı her ilişki benim için yanlıştır." (Görüşme:31, erkek, 22, 4.sınıf)

Sosyal Hizmet öğrencilerinin evlilik dışı ilişki ile ilgili düşüncelerinin daha çok olumsuz bir zeminde yer aldığı görülebilmektedir. Bu durumun nedeni evlilik dışı ilişkinin toplumumuz ile bağdaşmıyor olmasından kaynaklanıyor olabilir. Kimi katılımcılar da benzer olarak evlilik dışı ilişkiyi gayri ahlaki olarak bulmuşlardır. Aile ve Sosyal Politikalar Bakanlığı'nın yayınlamış olduğu Aile Yapısı Araştırması Araştırması'na (2006) göre de ülkemizde bireylerin çoğunluğunun evlilik dışı ilişki yaşamaya olumlu bakmadığı, bireylerin birlikteliği için evliliğin gerekli olduğu anlaşılmaktadır (Aile ve Sosyal Politikalar Bakanlığı, 2010: 97).

Flört Eden Kadın

Gayet doğal

"Gayet normal bir durum. Her insan hayatına devam ederken yanında bir destekçi olmasını ister." (Görüşme:2, kadın, 18, 1.sınıf)

"Yalnızlığını giderecek, sevdiği biriyle yan yana olmak istemiștir." (Görüşme:4, kadın, 18, 1.sınıf)

"Bence gayet olasıdır. Doğru insanı bulmak ilk seferde mümkün olmadığı için her birliktelikte evlilikle sonuçlanmaz. (Görüşme: 15, Kadın, 22, 2. Sınıf)

"Flört kötü bir durum değil kadın için de erkek içinde. Sevdiği adamla flört her kadının özgürlüğüdür."(Görüşme:16, kadın, 20, 2.sınıf)

"Yalnız hayatına birini almaya çalışan kadın. "(Görüşme:17, kadın, 19, 2.sınıf)

"Gayet normal bir şey olduğunu düşünüyorum.” ( Görüşme:22, kadın, 3.sınıf)

"Kendim de flört ediyorum normal bir davranış olarak görüyorum." (Görüşme:32, kadın, 4.sınıf)

"Flörtün yaşanması kadının karşı cinsle iletişimini kuvvetlendireceği, kişisel bakımını ve özgüvenini arttıracağı düşüncesindeyim.” (Görüşme:36, erkek, 23, 4.sınıf)

Evliliğe giden yol

"Bence bir kadın neyin, kimin ne olduğunu anlayabilmesi için aşırıya kaçmamak şartıyla tanıması flört etmesi gerektiğini düşünüyorum.” (Görüşme:3, kadın, 19, 1.sınıf)

"Daha sağlıklı bir evlilik için ahlaki kurallar çerçevesinde olduğu sürece gayet normaldir. Hatta evliliklerin bu şekilde gerçekleştirilmesi gerekir. " (Görüşme:12, erkek, 20, 2.sınıf)

"Ben de bir flört eden kadınım. Evleneceğim insanı kendim seçeceğim için haliyle görünüşten anlaşılmıyor tanımak gerekir. Görücü usulü evlilik bence saçma insan sevmediği bir insanla bir ömür geçiremez. Kadınlar flört etmeli ve eş tercihini kendi yapmalıdır." (Görüşme:40, kadın, 22, 4.sınıf)

"Evliliğe giden yolda birbirlerini tanımak için flört etmiştir." (Görüşme:8, erkek, 20, 1.sınıf)

"Evlilik öncesi birlikte geçirmiş oldukları süredir. Yani sevgili anlamında. Ama evlenmeden önce birbirini daha iyi tanımak, daha iyi anlamak için (tabi bu işi fazla ileriye götürmeden) günümüz toplumunda gerekli olandır." (Görüşme:27, erkek,23, 3.sinıf)

"Gelecekte iyi bir aile kurmak, birbirini daha iyi tanımak amacıyla yapılabilir." (Görüşme:28, erkek, 23, 3.sinif)

"Flört hayatını birleştirecek kişiyi tanımak için iyi bir süreçtir. ”(Görüşme:15, kadın, 22, 2.sınıf)

"Hayatını birleştirmeye giden yolda olması gereken bir durumdur. Her insan her insanla anlaşamaz ve bu yüzden de yanlış bir seçim yapmamak için flört hem kadın hem de erkek için olmalıdır." ( Görüşme:21, kadın, 23, 3.sinif)

"Flört etmek kimi zaman evlilik yolunda atılan adımdır, kimi zaman beraber güzel vakit geçirme adına kurulan birlikteliktir. (Görüşme: 37, Kadın, 24, 4. Sınıf)

Belirli bir sinurı olmalı

“Seviyeli bir ilişki olabilir.”(Görüşme:13, erkek,20, 2.sınıf) 
“Flört sayısının azlığı çokluğu flört eden kadın hakkında ne düşünmemiz konusunda bizi yönlendireceğini düşünüyorum.” (Görüşme:34, kadın, 21, 4.sınıf)

"Toplumun kurallarına aykırı olmadığı sürece flört ve flört eden kadın hakkında olumsuz düşünmüyorum." (Görüşme:5, kadın, 20, 1.sınıf)

"İlişkinin, yaşananların belirli bir sınırı olmalıdır. Flört halinde, evlilik dışı ilişkiye maruz kalmadan seviyeli bir ilişki olmalı flört aşaması." (Görüşme:26, kadın, 21, 3.sınıf)

Sosyal hizmet bölümü öğrencilerinin evlilik dış1 ilişki konusundaki düşüncüleri "olumlu” olmaktan çok uzakta iken flört konusundaki düşünceleri ilginç bir şekilde olumsuz değildir. Evliliğe giden yol veya gayet doğal olarak tanımladıkları flört sürecini evlilik için gerekli bir durum gibi gördükleri düşünülebilir. Çünkü aile tarihiyle ilgili yapılan araştırmalarda endüstri öncesi toplumlarda evlilikler bireylerin kendi seçimlerinden ziyade ailelerinin kararıyla gerçekleşirken, günümüz toplumunda bireyler kendi seçimleriyle evlenmektedir (Aile ve Sosyal Politikalar Bakanlığı, 2010: 33). Katılımcıların da ifadelerinden anlaşılacağı üzere flörte ilişkin genel bakış açısının değiştiği görülebilmektedir.

\section{Hayat Kadını}

Bataklığa düşmüş

"Kurtarılmaya muhtaç canlı. "(Görüşme:13, erkek,20, 2.sınıf)

“Kurtarılmaya muhtaç, mağdur insan. ”(Görüşme:11, erkek, 20, 2.sınıf)

"Hayatta iyi olanaklardan mahrum kalmış, mağdur kadın gelir. "(Görüşme:15, kadın, 22, 2.sınıf)

"Mağduriyetleri olan, hayatta sığınabileceği kimsesi olmayan bir kadın.” (Görüşme:17, kadın,19, 2.sınıf)

"Çok zor şartları olduğunu, hepsinin istemeyerek çalışmadığını ve kadınların b duruma düşmelerinin nedenini erkeklere bağlıyorum.” ( Görüşme:22, kadın, 3.sınıf)

"Allah yardımcıları olsun." (Görüşme:25, kadın, 21, 3.sınıf)

"Bir şekilde birilerinin tuzağına düşmüş ve tutsak kalmış, daha sonra kimisi bir meslek haline getirdiği için vazgeçmez ve sürdürür, kimisi ise yapmak zorunda kalır (tehdit ve şantaj).” (Görüşme:28, erkek, 23, 3.sınıf)

"Bir yığın hayal kırıklığı taşıyan kadındır." (Görüşme:5, kadın, 20, 1.sınıf)

"Bazı şeyler benim için kaderdir ve hayat kadınlarının bu durumlarından çok da memnun olduğunu sanmıyorum.” (Görüşme:4, kadın, 18, 1.sınıf)

"Kendi vücudundan para kazanması çok yanlış. ”(Görüşme:14, kadın, 20, 2.sınıf)

\section{Toplumun suçu}

"Birçok hayat kadınının yaptığı içi zevkle yaptığını düşünmüyorum aksine içinde bulundukları ve istemedikleri şartların onları buna zorladıklarını düşünüyorum.” (Görüşme:33, erkek, 21, 4.sınıf)

"Ne kadar yanlış bir yaşam biçimi olsa da kendi içinde tutarlı bir açıklaması vardır. Hiçbir kadın bu durumu istemez." (Görüşme:7, erkek, 20, 1.sınıf)

"Bu kadınlara acıyorum. Çeşitli sebeplerden dolayı bunları yaptıklarını duyuyorum ve kadınların bu durumlara düşmesi ve benim inancım içinde kadına (anneye) bu denli önem verilmesine rağmen kadınların bu durumlara düşmek zorunda kalmaları beni derinden etkiliyor.” (Görüşme:23, erkek, 21, 3.sınıf)

"Hangi koşulların onu bu işe zorladığını bilmeden yorum yapmak, asmak, kesmek çok yersiz olur. Bu açıdan bakarsak yorum yapmayı anlamsız buluyorum." (Görüşme:24, erkek, 22, 3.sınıf)

"Konuştuğum kadın kendi isteği ile yapmamış. Yaşadığı zorluk ve zorunlulukların bu yaşama ittiğini düşünüyorum." (Görüşme:32, kadın, 4.sınıf)

"Hayat kadınlarının şu anki durumlarından çok, onları bu yaşantıya sürükleyen nedenleri incelemek daha yerinde olacaktır. Bu nedenle de toplumun temel birimi olan ailenin güçlendirilmesi esastır." (Görüşme:37, kadın, 24, 4.sinif)

"Hiçbir kadın hayat kadını olmayı tercih etmez. Bu yüzden kadını bu konuma getiren nedenler göz önünde bulundurulmalıdır. Hayatında yanlış tercihler yapması, maddi olarak arayış içerisinde olması gibi nedenlerle bu hayata yönelmiş olabilir." (Görüşme:38, kadın, 23, 4.sınıf)

"Zordur herhalde. Sevmediğin bir insanın sana dokunması tuhaf bir duygu olmalı. hiçbir hayat kadınının bu işi severek yaptığını düşünmüyorum. Ekonomik yoksunluk nedeniyle bu durumda olduklarını düşünüyorum. Erkeklerin de aşağılamasını anlamıyorum da bir kadının aşağılamasını hiç anlamıyorum." (Görüşme:40, kadın, 22, 4.sınıf)

"Aile ve toplum tarafından dışlanan insanların arayış içinde iken kötü yola düşmeleri." (Görüşme:1, kadın, 19, 1.sinif)

“Toplumun dışlanmış kesimi.” (Görüşme:2, Kadın, 18, 1.Sınıf) 
Sosyal Hizmet öğrencilerinin hayat kadını ile ilgili düşünceleri yukarıda verilmiştir. Öğrencilerin çoğunluğunun hayat kadını ile "bataklığa düşmüş", "toplumun suçu" arasında bağlantı kurduğu görülmektedir. Ataerkil toplumlar cinsel ilişkiyi erkek için bir ihtiyaç olarak görmekte fuhuş ve fahişelik olgularını da bu ihtiyaçların karşılanması için kullanılan kavramlar olarak göstermektedir. Buna rağmen hayat kadınları fahişe damgasıyla karşı karşıya kalarak toplum tarafından "namusu lekelenmiş" kadın şeklinde anılabilmektedir (Hepşen, 2010: 53). Fuhuş işini salt ticari bir biçim olarak düşünmek en basta insanlık değerlerini ve onurunu hiçe saymak olacaktır. Bu nedenle fuhuş olgusuna, erkek egemen toplumun bir yaratısı olarak bakmak gerekmektedir. Ayrıca fiziksel ve ruhsal şiddeti doğuran, güç, mağduriyet ve para ekseninde dönen toplumsal bir sorun olarak adlandırılabilmektedir (Bat1, 2008: 223). Günümüz dünyasının yoksul, geri kalmış ülkelerinde kadın bir dış satım ürünü haline getirilmiştir. Kadınlara yönelik şiddet ve ayrımcıllı̆ın en yoğun yaşandığı fuhuşun yaygınlaşmasında; olumsuz ekonomik koşullar, aile patolojileri, din anlayışı ve töreler, kadın-erkek eşitsizliği, eğitimsizlik, her türlü malın satışını çıplak kadınla özdeşleştiren reklam dünyası etkili olduğu belirtilmektedir (Özerdoğan ve diğ., 2006: 2).

\section{SONUÇ}

Sosyal hizmet öğrencilerinin kadına yönelik ön yargıları değerlendirildiğinde çalışan kadın açısından en çok bağımsızlık-özgürlük temasının ön planda olduğu görülmektedir. Özellikle sosyal hizmetin temel ilkelerinden olan self determinasyon açısından öğrencilerin kadının kendi ayakları üzerinde durabilmesini ön plana çıkardıkları görülmektedir. İkinci olarak vurgulanan çalışan kadının durumunun yorucu ve zor olması da kadının evdeki rolüne yönelik kültürel beklentiler ile birlikte çalışma hayatının dengesini kurabilmesinin önemine değinmişlerdir. Kadın ve erkeğin eşit olduğu ileri sürülse bile erkeğin evin reisi olması gerektiğinin, ev işlerini kadının yapması gerektiğinin savunulması ülkemizde toplumsal cinsiyet rolünün etkisi ile rol ve sorumluluklarda eşitsizliğin devam ettiğini göstermektedir (Ergöl ve diğ., 2012). Kadın neye benzer sorusuna yönelik öne çıkan tema olan ilgi bekleyen narin vurgusu özel bir gereksinim grubu açısından kadının ön plana çıkarılması olarak düşünülebilir. Koruyucu anne teması da kadının annelik rolünün ve çocuk refahı alanındaki temel unsur olarak ön plana çıkmasının bir yansıması olarak değerlendirilebilir. Ev hanımına yönelik öğrencilerin görüşleri bir taraftan zor meslek diğer taraftan ev hanımlığının aslında monoton bir hayat olarak düşünülmesi gerektiğini belirtmektedir. Kadının boşanmasına yönelik "gayet doğal" vurgusunun yoğunluğu, yargılayıcı olmayan bir tutumu belirtmekte kadın erkek eşitliğine gönderme yapmaktadır. Boşanan kadını "toplumda dışlanan” olarak nitelendirenler sadece kız öğrencilerdir. Boşanmış insanlarla arkadaşlık yapmanın uygun olduğu söylense bile boşanmış insanlarla arkadaşlık yapanların sayısının çok az olduğu görülmüştür (Arıkan, 1996). Evlilik dışı ilişkide vurgulanan "doğru değil teması" evlilik kurumunun kültürel önemini ön plana çıkarmaktadır, bununla birlikte söz konusu durum yargılayıcı bir tavır tehlikesini de barındırmaktadır. Kadının flört etmesi öğrenciler tarafından normal karşılanmakta evliliğe giden bir yol olarak değerlendirilmektedir. Hayat kadınlığı konusunda toplumun sorumluluğuna gönderme yapılmakta, hayat kadınlığı bir sosyal sorun olarak değerlendirilmektedir. Ek olarak hayat kadının toplumsal konumu da bataklığa düşmekle özdeşleştirilmektedir.

Özellikle erkek öğrencilerin kadının ev içi konumuna vurgu yaptığı görülmektedir. "Çok gerekli olmadıkça çalışması taraftarı değilim.”; " Erkeğin görevi çalışmaksa kadınınki de ev işleridir.”; "gündüz vardiyası olmak şartıyla gayet normal bir durumdur."; "Annelik görevi aksarsa çalışmamalı.”; "Çalışma saat ve koşulları uygun ise"; "İyi bir şey çocuklarına çok yakından destek olduğu için."; "Bir kadının yeri evinin içidir. Bu konuda düşüncelerim tam pozitif yöndedir." gibi ifadeler erkek öğrencilere ait olup kadının çalışmasının uygun olmadığı belirtilmektedir. Erkek öğrencilere göre kadın çalışıyorsa bile yapacağı iş ev içindeki yapacaklarını etkilememesi gerekmektedir. Başka bir öğrenci de "Kadınların çalışması günümüz de bir gerekliliktir diyebiliriz. Ancak her bireyin kendi fitratına, yapısına uygun işleri yapması gerekir" diyerek kadının çalışması ile ilgili fitrat tartışmalarını vurgulamaktadır. Her ne kadar kadının çalışması ile ilgili olumsuz düşünceler erkek öğrenciler nezdinde ağırlıkta da olsa bu hususa katkı veren kadın öğrenciler de bulunmaktadır. Örneğin "Evli çalışan bir bayan için şartlar zor olabilir. veya "Ailesiyle ilgilenmekte zorlanan kadının çalışmaması daha mantıklı tabi." gibi ifadeler kadın öğrencilere ait olup kadının geleneksel ev içi sorumluluklarını hatırlatmaktadırlar.

Evlilik dışı ilişki yaşanması hem erkek hem kadın öğrenciler tarafından doğru bulunmamakta ve ayrıca gayri ahlaki bulunmaktadır. Ancak bu durumu kişilerin kendi kararı ve kendi yaşam tarzları neticesinde değerlendirenler de bulunmaktadır. Flört etme ile ilgili hem erkek hem de kadın öğrenciler bunun belirli bir sınırı olması gerektiğini düşünseler de flört etmeyi doğal ve evlilik için bir temel oluşturduğu konusunda hemfikirlerdir. Hayat kadını ile ilgili olarak hem erkek hem de kadın öğrenciler kadının bu işi yapmasının toplumun suçu olduğunu vurgulamaktadırlar. 
Kadına yönelik hizmetler hem aile genelinde hem de birey özelinde Türkiye'de geliştirilmesi gereken alanları temsil etmektedir. Öğrencilerin ön yargılarının farkında olabilmeleri, meslek hayatında karşılaşacakları durumlarda kadın müracaatçıları yargılamadan anlayabilmeleri ve onların self determinasyonlarını savunabilmeleri açısından hayati önemdedir. Bu anlamda hem kültürel farkındalık hem de kişisel farkındalık çalışmalarının müfredattaki önemi ön plana çıkmaktadır. Öğrencilerin kadının kamusal alandaki görünürlüğünün ve ev içine hapsolmasının ne anlama geldiğini ve bunun sonuçlarını kavrayabilmeleri açısından toplumsal cinsiyet ile ilgili eğitimleri almaları gerekmektedir. Bu noktada ayrımcılık karşıtı uygulamanın bireylerin sorunların üstesinden gelmesinde ve özgürleşmelerinde toplumsal bütünleşmeyi destekleyen ve farklılıklara saygı duyan uygulama temelli bir disiplin olan sosyal hizmet için gerekli olduğu vurgulanmaktadır (Cankurtaran ve Beydili, 2016). Sosyal hizmet eğitim-öğretim müfredatının öğrencileri değiştirici ve geliştirici bir yanı olduğu düşünüldüğünde toplumsal cinsiyet ile ilgili eğitimlerinin öğrencinin sorgulama kapasitesine geliştirebilmesi gerekmektedir. Örneğin Akçay ve Başer (2018) tarafindan yapılan çalışmada Toplumsal Cinsiyet ve Sosyal Hizmet dersini alan öğrencilerin toplumsal cinsiyet algısında anlamlı bir farklılık olduğu, dersi almayan öğrencilerin toplumsal cinsiyet algısında ise anlamlı bir farklılık olmadığı görülmüştür. Diğer taraftan toplumsal cinsiyet konusunun çok geniş ve kapsamlı bir alana sahip olduğu unutulmamalıdır. Çalışma yaşamı, kalkınma, şiddet, medya, kültür, sağlık, politika gibi birçok etmenle beraber ele alınmaktadır. Bu kapsamda sosyal hizmet öğrencilerinin de toplumsal cinsiyet ve birlikte ele alındığı etmenler noktasında bilgi sahibi olması gerekmektedir. Bunu gerçekleştirebilmek için başlı başına müfredatta toplumsal cinsiyet dersine yer verileceği gibi müfredatta yer alan dersler içerisine de konular yedirilebilir. 


\section{KAYNAKLAR}

Akçay, S., \& Başer, D. (2018). Toplumsal Cinsiyet ve Sosyal Hizmet Dersinin Sosyal Hizmet Öğrencilerinin Toplumsal Cinsiyet Algısına Etkisi. F. Yamaner, \& E. Eyuboğlu içinde, İnsan, Toplum ve Spor Bilimleri Araştırma Örnekleri (s. 287-296). Ankara: Nobel Akademik Yayıncilık.

Aker, S., Dündar, C. ve Pekşen, Y. (2007). Sokaktakiler, Yazılı Basın ve Damgalama. Aile ve Toplum Eğitim- Kültür ve Araştırma Dergisi, 3 (11), 83-90.

Akgül Sarpkaya, O. (2013). Boşanmış Kadınlarda Toplumsal Baskıya Direnme Stratejileri: Van Örneği. Uluslararası Sosyal Araştırmalar Dergisi, 6 (26), 29-50.

Aktaş, Y. (1994). Çalışan Anne ve Çocuğu. Yaşadıkça Eğitim, 36, 7-11.

Alagözlü, N. (2009). Dil ve Cins: Türkçe Atasözlerinde ve Deyimlerde Kadın Üzerine Eğretilemeler ve Toplum-Bilişsel Yap1. International Journal of Central Asian Studies, 13, 37-48.

Alço, N. (2011). Zordur Kadın Olmak. Hürriyet Gazetesi, (1 Ocak 2011).

Arıkan, Ç. (1996). Halkın Boşanmaya İlişkin Tutumları. Ankara: T.C. Başbakanlık Aile Araştırma Kurumu Başkanlığı.

Aydın, O. ve Baran, G. (2010). Toplumsal Değişme Sürecinde Evlenme Ve Boşanma. Toplum ve Sosyal Hizmet, 21 (2), 117-126.

Batı, U. (2008). Hayatın Arka Sokakları: Seks İşçilerine Karşı Toplumsal Şiddet. Sosyal Bilimler Enstitüsü Dergisi, 10 (2), 200-230.

Baykara Acar, Y. (2014). Türkiye'de Kadın Olmak. V. Işıkhan içinde, Doç.Dr. Şener Koçyıldırım'a Armağan Sosyal Hizmet ve Toplumla Çalışma (s. 143-156). Ankara: Sosyal Hizmet Araştırma, Uygulama ve Geliştirme Derneği.

Berberoğlu, U., Çelikkalp, U., Saraçoğlu, G. V. ve Tokuç, B. (2011). Sağlık Yüksekokulu Öğrencilerinin Evlilik Dış1 Cinsel İlişki, İstemli Düşükler ve Kontraseptik Kullanımı, Türk Halk Sağlığı Dergisi, 9 (3), 172-179.

Beydili, E., Yıldırım, B. ve Demiröz, F. (2013). Sosyal Hizmet Perspektifinden Feminizm Üzerine Bir Gözden Geçirme: Kadın Çalışmlarında Erkek İşbirliği. Aile ve Kadın Sempozyumu (s. 45-50). Kırıkkale: Kırıkkale Üniversitesi Yayınları.

Bilican Gökkaya, V. (2011). Türkiye'de Kadına Yönelik Ekonomik Şiddet. C.Ü. İktisadi ve İdari Bilimler Dergisi, 12 (2), 101-112.

Bulut, M. (2008). Kadınlarda Boşanma ve Kültür İlişskisi. Toplum ve Sosyal Hizmet, 19(2), 111-118.

Büyüköztürk, Ş., Çakmak, E. K., Akgün, Ö. E., Karadeniz, Ş. ve Demirel, F. (2017). Bilimsel Araştırma Yöntemleri. Ankara: Pegem Akademi.

Cankurtaran, Ö. ve Beydili, E. (2016). Ayrımcılık Karşıtı Sosyal Hizmet Uygulamasının Gerekliliği Üzerine. Toplum ve Sosyal Hizmet, 27(1), 145-159.

Coşkun, Ş. (2004). Kültürlerarası İletişim Sürecinde Kalıp Düşüncelerin ve Ön yargıların Rolü: "Antalya'da Yaşayan Güneydoğulular İle Antalya Yerlileri Arasındaki Kalıp Düşünceler Ve Ön yargılar”, Yükseklisans Tezi, Ankara Üniversitesi Sosyal Bilimler Enstitüsü.

Dalkılıç, M. (2011). Zordur Kadın Olmak. Hürriyet Gazetesi, (1 Ocak 2011).

Doğan Haber Ajansı (2014). Başkan 'Kadın Yardımcı Olmaz' Dedi, Kadın Üye İstifa Etti. Radikal Gazetesi, (7 Nisan 2014).

Dolmacı, N. ve Şalvarcı Türeli, N. (2012). Varlığını Sürdüren Bir Sorun Olarak Toplumda ve İş Yaşamında Kadına Yönelik Farklı ve Ayrımcı Tutumlar. Akademik Bakış Dergisi (33), 1-15.

Dönmez, A. (1990). Kadınlar Kadınlara Karşı Ön yargılı Mı? Ankara Üniversitesi Dil ve Tarih Coğrafya Fakültesi Dergisi, 33 (1-2), 103-122.

Ekiz, D.(2003). Eğitimde Araştırma Yöntem ve Metotlarına Giriş. Ankara: Anı Yayıncılık.

Eliuz, Ü. (2011). Cinsel Kimlik Paniği: Kadın olmak. Turkish Studies International Periodical For The Languages, Literature and History of Turkish or Turkic, 6 (3), 221-232.

Erbay E. ve Tuncay T. (2006). Sosyal Hizmet Bakışıyla Kadın İstihdamı. Toplum ve Sosyal Hizmet Dergisi, 17 (2), 25 40.

Ergöl, Ş., Koç, G., Eroğlu, K. ve Taşkın, L. (2012). Türkiye'de Kadın Araştırma Görevlilerin Ev ve İş Yaşamlarında Karşılaşıtıları Güçlükler. Yükseköğretim ve Bilim Dergisi, 1 (2) , 43-49.

Eroğlu K. ,Taşkın L. Vefikuluçay D. ve Zeyneloğlu S. (2007). Kafkas Üniversitesi Son Sınıf Öğrencilerinin Toplumsal Cinsiyet Rollerine İlişkin Bakış Açıları, Hemşirelik Yüksekokulu Dergisi, 26-38.

Guest, G., Bunce, A., \& Johnson, L. (2006). How Many İnterviews Are Enough? An Experiment With Data Saturation And Variability. Field Methods, 18, 59-82.

Gülaçtı, N. (2012). Sanatsal Bir Obje Olarak Kadın ve Bazı Toplumlarda Kadına Bakış. İdil Dergisi,1 (2) , 76-91

Gülendam, R. (2007). Türk Kadınının Aile İçindeki Yeri ve Rolünün Yeri ve Rolünün Modern Türk Edebiyatına Yansımasi: 1960-1980. SDÜ Fen Edebiyat Fakültesi (15), 165-182.

Gürel, N. (2011). Kişilik Psikolojisi, Ön yargıların Psikolojisi ve Kamuoyu: Gordon Allport ve Walter Lippmann’ in Görüşleri Çerçevesinde Bir Değerlendirme. Ankara Üniversitesi Sosyal Bilimler Enstitüsü Dergisi, 2 (2), 101-134.

Gürses, İ. (2005). Ön yargının Nedenleri, Uludağ Üniversitesi İlahiyat Fakültesi Dergisi, 14 (1), 144-161.

Hepşen, Ö. (2010), Tevrat, İncil Ve Kuran-1 Kerim’de Kadın Bedeni, Ankara Üniversitesi Sosyal Bilimler Enstitüsü Yayınlanmamış Yüksek Lisans Tezi. 
İlhan, R. S. ve Çevik, A. (2013). Ön yargıların Psikolojisi:Psikodinamik Bir Gözden Geçirme. Nesne-Psikoloji Dergisi, $1(1), 50-65$.

Kaarasar, N. (2008). Bilimsel Araştırma Yöntemi. Ankara: Nobel Yayıncılık.

Kalaycı-Kırlığlu, H. İ., Akarçay, D., Kırlığlu M. (2016). Atasözleri ve Deyimlerde Kadına Yönelik Şiddetinİzleri: Niteliksel Bir Çalışma. 8 (4), 101-122.

Karmaz, E. (2013). Ücretli Çalışmayan Evli Kadınların Ev Dışına Çıkmayı Meşrulaştırma Şekilleri. M. Tuna, Ü. Bozyer ve E. Açık Turğuter (Dü) içinde, Uluslararası Katılımlı VII. Ulusal Sosyoloji Kongresi Toplumsal Yapılanmalar: Geçişler, Kesişmeler, Sapmalar Bildiri Kitabı I (s. 21-32). Muğla: Muğla Sitkı Koçman Üniversitesi.

Kocacık, F. ve Gökkaya, V. (2005). Türkiye'de Çalışan Kadınlar ve Sorunları. Çukurova Üniversitesi İktisadi ve İdari Bilimler Dergisi, 195-218.

Özerdoğan, N. , Sayıner, D. , Köşgeroğlu, N. ve Örsan, Ö. Kadın ve Fuhuş Olgusu (The Fact Of Women and Prostitution). Second İnternational Conference On Women's Studies. April 27-28 2006; Center For Women's Studies, EMU, Turkish Republic Of Northern Cyprus.

Sarpkaya, O. A. (2013). Boşanmış Kadınlarda Toplumsal Baskıya Direnme Stratejileri: Van Örneği. Uluslararası Sosyal Araştırmalar Dergisi, 6 (26), 30-50.

Sürgevil, O. (2008). Farklılık Kavramına ve Farklılık Yönetimine Temel Oluşturan Sosyo-Psikolojik Kuramlar ve Yaklaşımlar. Balıkesir Üniversitesi Sosyal Bilimler Enstitüsü Dergisi, 11 (20), 111-124.

Şengör, C. (2011). Zordur Kadın Olmak. Hürriyet Gazetesi, (1 Ocak 2011).

T.C. Başbakanlık Aile ve Sosyal Politikalar Bakanlığı. (2010). Aile Yapısı Araştırması 2006. Ankara: Diner Ofset.

T.C. Başbakanlık Çalışma ve Sosyal Güvenlik Bakanlığı. (2010). AB Koordinasyon Dairesi Başkanlığı Bülteni. Ankara. TDK. (2014). 10 Nisan 2014 tarihinde http: // www. tdk. gov. tr. adresinden erişildi.

TUİK. (2013). Türkiye İşü̈cüne Katılım Oranı. Retrieved from: http: // www. tuik. gov. tr/ Gosterge. do?id=35708metod= İlgili Gösterge.

Türkkahraman, M. ve Şahin, K. (2010). Kadın ve Kariyer. Alanya İşletme Dergisi, 2 (1), 75-88.

Uygun, S. (2006). "Üniversite Gençlerinin "Öteki” Kimliklere Karşı Ön yargıları", Akademik Araştırmalar Dergisi, (29), 2-7.

Ümit, A. (2011). Zordur Kadın Olmak. Hürriyet Gazetesi, (1 Ocak 2011).

Yıldırım, A. ve Şimşek, H. (2013). Sosyal Bilimlerde Nitel Araştırma Yöntemleri. Ankara: Seçkin Yayıncılık.

Yılmazçoban M. (2008). Flört ve Görücü Usulü Evliliklerde Psiko-sosyal Özelliklerin Etkisi: Demirci Örneği. Sakarya Üniversitesi Sosyal Bilimler Enstitüsü Yayınlanmamış Doktora Tezi. 